\title{
Computerised Tomographic Evaluation of Structural Variations in Sinonasal Region and its Clinical Correlation
}

\author{
Research Article
}

Sahu $\mathrm{A}^{1 *}$, Mukherjee $\mathrm{SN}^{2}$, Rabin $\mathrm{S}^{3}$, Praneeth $\mathrm{K}^{1}$, Sahu $\mathrm{V}^{4}$, Kavita $\mathrm{G}^{5}$

${ }^{1}$ Pursuing DNB ENT, Department of ENT and HNS, downtown hospital, Guwahati, Assam, India.

${ }^{2}$ Senior consultant, Department of ENT and HNS, downtown hospital, Guwahati, Assam, India.

${ }^{3}$ Senior consultant, Department of radiology, downtown hospital, Guwahati, Assam, India.

${ }^{4}$ Assistant professor, Department of oral \& maxillofacial surgery, Government dental college and hospital, Nagpur, India.

${ }^{5}$ Consultant Oral \& maxillofacial surgeon, Nagpur, India.

\section{Abstract}

Introduction: The endonasal as well as paranasal anatomy is highly variable and can encroach upon the osteomeatal complex and narrow the osteomeatal channels.

Aims And Objectives: To study on CT scan, the incidence of structural variations in sinonasal region and its correlation with sinusitis.

Material And Methods: It's a cross sectional study on 106 cases done over 1 year.

Results And Observations: On the basis of clinical diagnosis chronic sinusitis was seen in $90(84.9 \%)$ cases and gross polyposis in $16(15.1 \%)$ cases. CT scan anatomical variations seen were as follows: Concha bullosa $64(60.37 \%)$, aggernasi cell in $58(54.7 \%)$, PMT in $28(26.41 \%)$, Large ethmoidal bulla in $18(16.98 \%)$, uncinate pneumatization in $12(11.3 \%)$, haller cell in $18(16.98 \%)$ and onodi cell in $12(11.35 \%)$ cases.

Maxillary sinus was most commonly involved in $90(84.9 \%)$ cases and least common involved was sphenoid sinus in 14 $(13.2 \%)$ cases. Among the 5 different patterns of CRS on CT scan most common was OMC pattern noted in $32(30.18 \%)$ cases followed by infundibular pattern in $31(29.24 \%)$, sporadic or unclassified unit pattern in $25(23.58 \%)$, sinonasal polyposis in $10(9.43 \%)$ cases and SER pattern in $08(7.54 \%)$ cases.

Conclusion: Rhinosinusitis commonly affects working population with female preponderance. Anatomical variation is observed to be one of the predominant causes for OMC block as well as sinusitis and CT is the paramount modality to study and analyze them.

Keywords: Computed Tomography (CT); Paradoxical Middle Turbinate (PMT); Osteo-Meatal Complex (OMC); Spheno-Ethmoidal Recess (SER).

\section{Introduction}

Human beings are individualistic and this is reflected in their anatomy, which is subject to a large number of anatomical variations. The endonasal as well as paranasal anatomy is highly variable [1] and the variations like septal deviations, concha bullosa, aggernasi, PMT, pneumatized uncinate etc. can encroach upon the OMC and narrow their channels [2]. This leads to impaired drainage and ventilation of the paranasal sinuses which primarily cause sinusitis.

Stammberger and Hawke in 1993 have shown that CT scan of PNS provide a road map to identify significant anatomic abnormalities, exact location of obstruction and severity of the disease [3]. It has the ability to optimally display bone, soft tissue and air. It provides an accurate description of both anatomy and extent of disease in and around PNS. CT scan is gold standard investigation for CRS diagnosis [4].

\section{Aims and Objectives}

1. To study on CT scan, the incidence of structural variations in sinonasal region.

2. To study the correlation between sinonasal anatomical

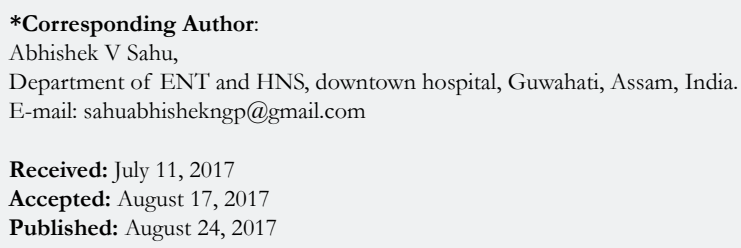

Citation: Sahu A, Mukherjee SN, Rabin S, Praneeth K, Sahu V, Kavita G. Computerised Tomographic Evaluation of Structural Variations in Sinonasal Region and its Clinical Correlation. Int J Clin Exp Otolaryngol. 2017;3(5):78-86. doi: http://dx.doi.org/10.19070/2572-732X-1700015

Copyright: Sahu $\mathbf{A}^{\circ}$ 2017. This is an open-access article distributed under the terms of the Creative Commons Attribution License, which permits unrestricted use, distribution and reproduction in any medium, provided the original author and source are credited. 
variations and sinusitis.

3. To compare the results of this study with the results of the previous workers.

\section{Material and Methods}

Study Area: ENT department, down town Hospital, Guwahati, Assam.

Study Population: Patients fulfilling the inclusion criteria and attending the ENT OPD and IPD of downtown hospital were included in the study.

Study Design: Cross Sectional Study.

Sample Size: 106 cases.

Sample Period: 1 year from $4^{\text {th }}$ December 2015 to $3^{\text {rd }}$ December 2016.

\section{Inclusion Criteria}

- Chronic Rhinosinusitis diagnosed as per the criteria by AAOHNS Task Force 1997

- Patients more than 12 years of age

- Septal pathologies like DNS

- Sinonasal polyposis

- Nasal obstruction due to different causes like anatomical variation

- Headache due to nasal pathology

\section{Exclusion Criteria}

- Acute and Subacute Rhinosinusitis

- Patients less than 12 years age

- Septal pathologies like abscess, hematoma and perforation

- Facial trauma and fracture nasal bone

- Sinonasal malignancies

- Previous nasal surgeries

- Granulomatous nasal conditions

- Fungal nasal diseases

- Complicated sinusitis

- Known disorder of ciliary motility like immotile ciliary syndrome, Kartageners syndrome, Down syndrome and cystic fibrosis

- Those not willing for CT scan

\section{Methodology}

During a 1-year period, a total of 106 cases were evaluated who had attended the OPD or IPD of ENT, downtown hospital, Guwahati, Assam. The patient's clinical features were noted as per AAO-HNS Taskforce 1997 parameters into major and minor. 2 major factors or 1 major factor and 2 minor factors constitute a strong history for CRS.

A thorough clinical examination was done and the diagnosis of rhinosinusitis was established. All the patients in acute phase of the disease were treated conservatively with a course of antibiotics, topical and oral decongestants, antihistaminics and steroids. The patients who returned for follow up were again clinically evaluated for subjective relief in symptoms and objectively by thorough clinical examination. The patients with persistent symptoms and signs were counseled regarding imaging of nose and PNS by CT scan and also about the need for further endoscopic evaluation and surgery.

Written informed consent was taken and data regarding the patient was collected in a case proforma as per annexure.

\section{Technique of doing CT Scan}

Before undergoing CT scan, the patient was instructed to clean their noses by blowing out any secretions and/or suction clearance of the nose and PNS was done. CT scan was done using a 16 slice CT machine.

\section{Patient Position}

Supine position with head extended. In patients in whom head extension was contraindicated due to cervical spondylosis, gantry tilt was suitably adjusted.

\section{Angulations}

In the coronal study, taking hard palate as reference axis, the plane of section was perpendicular to this structure. Direct scans $3 \mathrm{~mm}$ in thickness were made, from the anterior walls of the frontal sinuses (nasion) to the posterior wall of the sphenoid sinus. $0.6 \mathrm{~mm}$ high resolution coronal and axial scans were then reconstructed and reviewed.

\section{Exposures}

$120 \mathrm{kV}, 80 \mathrm{~mA}$ with 23 second scan time, window width of 2500 to $3000 \mathrm{HU}$.

Pattern of disease on CT scan was noted as described by Sonken et al., (1991) and includes:

1. Infundibular pattern

2. Osteomeatal complex pattern

3. Sphenoethmoid recess pattern

4. Sinonasal polyposis pattern

5. Sporadic (unclassifiable) pattern

The data was processed using Microsoft Excel software. For statistical analysis of the data showing relationship of anatomical variation and presence of sinusitis, $\chi^{2}$ test was used as tests for significance. The statistical analysis was done using SPSS-16 software.

\section{Results and Observations}

Present study included 106 patients of which $90(84.9 \%)$ cases were of chronic rhinosinusitis and $16(15.1 \%)$ of gross polyposis on clinical examination. Maximum patients i.e. 42 (39.62\%) cases were of 21-30 years age group followed by 28 (26.4\%) cases between $31-40$ years. Youngest patient was 13 years old and eldest was 68 years old. We found a female preponderance with a ratio of 1.52:1.

Various clinical features presented by all patients were categorized 
into major and minor factors as per task force 1997. Among major factors, most common was nasal obstruction seen in $96(86.7 \%)$ cases, followed by nasal discharge in $84(79.2 \%)$ cases, least common was hyposmia or anosmia seen in $16(15.09 \%)$ cases. In minor factors, headache was the most common presenting factor seen in $74(69.81 \%)$ cases, followed by fatigue in $34(32 \%)$ cases and fever in $24(22.6 \%)$ cases. Least common among the minor factors was halitosis seen in $14(13.2 \%)$ cases.

In present study most common septal variation was septal deviation seen in $88(83 \%)$ cases and more towards left side in 52 $(62.5 \%)$ cases. Severe type of septal deviation was most common, seen in $46(43.3 \%)$ cases of which $24(22.6 \%)$ were to left and $22(20.7 \%)$ to right followed by moderate septal deviation in 30 $(28.3 \%)$ cases and mild in $12(11.3 \%)$ cases. Septal deviation with spur is seen in 40 cases $(37.73 \%)$ of which 24 were on left side and 16 on right side. Septal pneumatization is seen in $50(47.1 \%)$ cases. (Table 1)

In present study we noted presence of aggernasi cells in 58 $(54.7 \%)$ cases, of which $20(18.8 \%)$ were on right side \& 38 $(35.8 \%)$ had bilateral. Concha bullosa was seen in $64(60.37 \%)$ cases. It was bilateral in $30(28.3 \%)$ cases, on right side in $22(20.75$ $\%$ ) cases and on left side in $12(11.3 \%)$ cases.

Paradoxically curved middle turbinate was reported in $28(26.41 \%)$ cases which included $20(18.8 \%)$ cases on the left side, $4(3.7 \%)$ cases on the right side and bilaterally in $4(3.7 \%)$ cases. Uncinate pneumatization was seen in $12(11.3 \%)$ cases, 10 (9.43\%) cases of which were bilateral and only $2(1.89 \%)$ cases were to right side.

Ethmoid bulla was seen to be enlarged in 18 (16.98\%) cases. It was encountered bilaterally in $10(9.4 \%)$ cases, on the left side in $06(5.6 \%)$ cases and on the right side in $02(1.89 \%)$ cases. Haller cells were found in $18(16.98 \%)$ cases, mainly on left side in 08 $(7.5 \%)$ cases followed by $06(5.66 \%)$ cases on right side and 04 $(3.7 \%)$ cases on both sides. Onodi cells were seen in $12(11.35 \%)$ cases of which $08(7.5 \%)$ cases had it on left side and 04 cases had it on right side.

In present study we found concha bullosa in $64(60.3 \%)$ cases of which most common was lamellar type seen in $40(37.73 \%)$ cases that was bilateral in $18(16.98 \%)$ cases and unilateral in 22 $(20.75 \%)$ cases. This was followed by bulbous and extensive type seen in $12(11.32 \%)$ cases each and both types were bilateral in 06 $(5.67 \%)$ cases and unilateral in $06(5.67 \%)$ cases.

In present study we found superior attachment of UP mainly to lamina papyracea in $70(66 \%)$ cases on left side and $48(45.2 \%)$ on right side. This was followed by attachment to middle turbinate in $40(37.2 \%)$ cases on right and $28(26.4 \%)$ cases on left. Attachment to skull base was seen in $18(16.9 \%)$ cases on right and $08(7.54 \%)$ cases on left.

In present study, frontal cells were seen in $30(28.30 \%)$ cases where type I is most commonly seen in $16(53.3 \%)$ cases followed by type II in 8 (26.6\%) cases, type III in $04(13.3 \%)$ cases and least common type IV in only $02(6.6 \%)$ cases.

In present study, we found sinus opacification as most common in maxillary sinuses in $90(84.9 \%)$ cases followed by anterior ethmoidal air cells in $54(50.94 \%)$ cases and frontal sinus in 20 $(18.9 \%)$. Posterior ethmoid sinuses were opacified in $16(15.09 \%)$ cases and sphenoid sinus in $14(13.2 \%)$ cases being the least common. (Figure 1, Table 2)

In present study of 106 patients we have noted different patterns of disease on CT imaging as described by Sonken et al., (1991). OMC pattern of disease was most commonly noted in 32 $(30.18 \%)$ cases followed by Infundibular pattern in $31(29.24 \%)$ cases and sporadic/unclassified in $25(23.58 \%)$ cases, sinonasal polyposis pattern was seen in $10(9.43 \%)$ cases and least common was SER pattern noted in 08 (7.54\%). (Figure 2, Table 3)

In present study we found infundibular pattern was associated with septal deviation on same side of disease in 21 (67.74\%) cases, concha bullosa in $18(58.06 \%)$ cases and PMT in $14(45.16 \%)$ cases.

In OMC pattern, septal deviation was noted in $12(37.5 \%)$, concha bullosa in $21(65.62 \%)$ and PMT in $6(18.75 \%)$ cases on same side of disease. In SER pattern, septal deviation was seen in $2(25 \%)$ and PMT in $5(62.5 \%)$ cases on same side of disease. In sinonasal polyposis pattern, septal deviation was seen in $4(40 \%)$ and concha bullosa in $6(60 \%)$ cases on same side of disease. Sporadic pattern of disease was associated with septal deviation in $14(56 \%)$, concha bullosa in $6(24 \%)$ and PMT in $4(16 \%)$ cases on same side of disease.

In present study, we found left sided septal deviation was associated with right sided concha bullosa in 14 cases and right side septal deviation with left sided concha bullosa in 7 cases. Septal deviation with concha bullosa on same side was found in 9 cases. But there was no significant association between side of septal deviation and presence of concha bullosa on contralateral side $[\mathrm{P}=0.25$ which is not significant because $\mathrm{P}>0.05]$.

Table 1. Distribution Of Cases According To The Anatomical Variation Detected On CT Imaging.

\begin{tabular}{|c|c|c|c|}
\hline Anatomical Variation & Right & Left & Bilateral \\
\hline Aggernasi cells & $20(18.8 \%)$ & - & $38(35.8 \%)$ \\
\hline Concha bullosa & $22(20.75 \%)$ & $12(11.3 \%)$ & $30(28.3 \%)$ \\
\hline Paradoxically curved middle turbinate & $04(3.7 \%)$ & $20(18.8 \%)$ & $04(3.7 \%)$ \\
\hline Pneumatized Uncinate Process & $02(1.89 \%)$ & - & $10(9.43 \%)$ \\
\hline Large Ethmoidal bulla & $02(1.89 \%)$ & $06(5.66 \%)$ & $10(9.43 \%)$ \\
\hline Haller cells & $06(5.66 \%)$ & $08(7.5 \%)$ & $04(3.7 \%)$ \\
\hline Onodi cells & $04(3.7 \%)$ & $08(7.5 \%)$ & - \\
\hline
\end{tabular}


Figure 1. Bilateral haller cell (downward arrow) with right sided maxillary sinusitis (star).

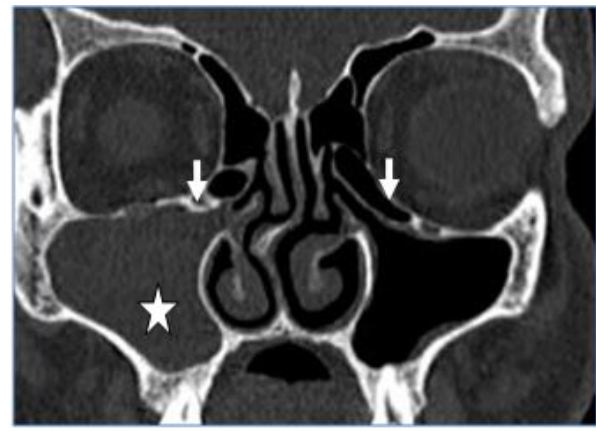

Table 2. Distribution Of Cases According To The Pattern Of Diseases On CT Scan.

\begin{tabular}{|c|c|c|c|c|}
\hline \multirow{2}{*}{ Pattern of disease } & \multicolumn{4}{|c|}{ Number of nasal cavities (2 in each patient) } \\
\cline { 2 - 5 } & Right & Left & Bilateral & Total \\
\hline Infundibular pattern & $07(6.60 \%)$ & $16(15.09 \%)$ & $08(7.54 \%)$ & $31(29.24 \%)$ \\
\hline OMC pattern & $05(4.71 \%)$ & $09(8.49 \%)$ & $18(16.98 \%)$ & $32(30.18 \%)$ \\
\hline SER Pattern & $02(1.89 \%)$ & $02(1.89 \%)$ & $04(3.77 \%)$ & $08(7.54 \%)$ \\
\hline Sinonasal polyposis pattern & $02(1.89 \%)$ & $07(6.60 \%)$ & $01(0.94 \%)$ & $10(9.43 \%)$ \\
\hline Sporadic/unclassified pattern & $08(7.54 \%)$ & $09(8.47 \%)$ & $08(7.54 \%)$ & $25(23.58 \%)$ \\
\hline
\end{tabular}

Figure 2. Left sided Osteomeatal pattern sinusitis.

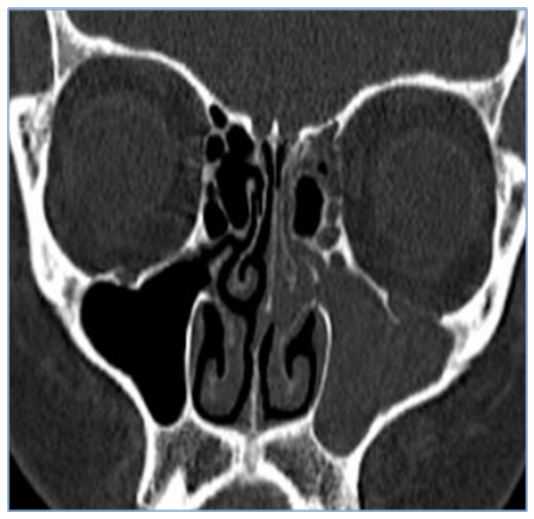

Table 3. Distribution Of Cases According To Radiological Pattern Of Disease And Its Association With Anatomical Variations.

\begin{tabular}{|c|c|c|c|c|}
\hline \multirow{2}{*}{ Pattern of Disease } & \multirow{2}{*}{$\begin{array}{c}\text { Number of } \\
\text { Patients }\end{array}$} & \multicolumn{3}{|c|}{$\begin{array}{c}\text { Anatomical Variation } \\
\text { on Side of Disease * }\end{array}$} \\
\cline { 3 - 5 } & & DNS & CB & PMT \\
\hline Infundibular pattern & $31(29.24 \%)$ & 21 & 18 & 14 \\
\hline OMC unit pattern & $32(30.18 \%)$ & 12 & 21 & 06 \\
\hline SER pattern & $08(7.54 \%)$ & 02 & - & 05 \\
\hline Sinonasal polyposis pattern & $10(9.43 \%)$ & 04 & 06 & - \\
\hline Sporadic pattern & $25(23.58 \%)$ & 14 & 06 & 04 \\
\hline
\end{tabular}

*Anatomical variation on the side of sinusitis was consider in ipsilateral disease and in bilateral disease both sides were considered.

In present study we found septal deviation in 88 (83\%) cases where moderate septal deviation was more frequently associated with sinusitis on same side in $21(70 \%)$ cases. Among severe septal deviations, we found sinusitis on the same side in 26 (56.52\&) cases and among mild septal deviations in $6(50 \%)$ cases. We found significant association of moderate septal deviation with sinusitis [chi-square test $\mathrm{x}^{2}=4.8, \mathrm{DF}=1, \mathrm{P}=0.02$ ]

In this study, we found concha bullosa in $64(60.3 \%)$ cases of which $40(37.73 \%)$ were lamellar and $25(62.5 \%)$ of those were seen on side of disease. Bulbous and extensive types were seen in $12(11.32 \%)$ cases each. 5 cases in the bulbous concha and 8 cases in extensive concha were associated with sinusitis on same side. 
There was no significant association between the type of concha bullosa and sinusitis on same side of disease [P > 0.05] (Figure 3).

\section{Discussion}

In present study out of 106 cases, maximum patients were between the age group of 21 - 30 years i.e. $42(39.62 \%)$ cases followed by $28(26.4 \%)$ cases in $31-40$ year age group. The findings in the present study correlate well with the other studies listed below having most of their presentation in the same age group. This is the most active age group and comprises the most productive age group of society (Table 4).

In present study we found female preponderance in cases of CRS with ratio of 1.52:1 which correlate well with the other studies listed below. It was reported that female dominance was due to hormonal changes that occurs during puberty, pregnancy, menstruation and sexual excitement due to vasomotor imbalance leading to frequent sinusitis. (Table 5)

Present study included 106 patients where 90 (84.9\%) chronic sinusitis and $16(15.1 \%)$ gross polyposis cases found on clinical examination, while study conducted by Jones et al., (1997) had $75 \%$ CRS and $25 \%$ diffuse polyposis [13].
The most common major symptom seen in the present study is nasal obstruction in $96(86.7 \%)$ cases, followed by nasal discharge/ post nasal drip in $84(79.2 \%)$ cases. Least common presenting symptom was hyposmia or anosmia seen in $16(15.09 \%)$ cases. In minor symptoms, most common was headache seen in 74 $(69.81 \%)$ cases, followed by fatigue in $34(32 \%)$ cases and fever in $24(22.6 \%)$ cases. Least common symptom among the minor factors was halitosis in $14(13.2 \%)$ cases.

Rohit Saxena et al., (2010) studied 60 patients of CRS and reported post nasal drip as most common major symptom seen in $46(76.7 \%)$ cases followed by nasal obstruction in $43(71.7 \%)$ cases. Among minor symptoms headache was seen in $36(60 \%)$ cases followed by cough in $20(33.3 \%)$ and earache in $8(13.3 \%)$ cases [14]. In present study most common septal variation was septal deviation seen in $88(83 \%)$ cases, more common on left side $52(62.5 \%)$ cases and right side seen in $36(33.96 \%)$ cases. Mamatha in 2010 in his study showed the prevalence of DNS ranging from $14.1 \%$ to $80 \%$ [15] as reported by other workers: Dutra and Marchiori 14.1\%; Kinusi et al., 23.3\%; Arslan et al., $36 \%$; Asruddin 38\% ; Earwaker 44\%; Maru 55.7\% and Pinas P et al., $80 \%$. In other studies, these findings are Zinreich SJ et al., (1988) [16] 21\%, Bolger WE et al., (1991) [5] 18.8\%, Jareoncharsri

Figure 3. Bilateral concha bullosa (downward arrow) with right maxillary sinusitis (star) and left septate maxilla (side arrow).

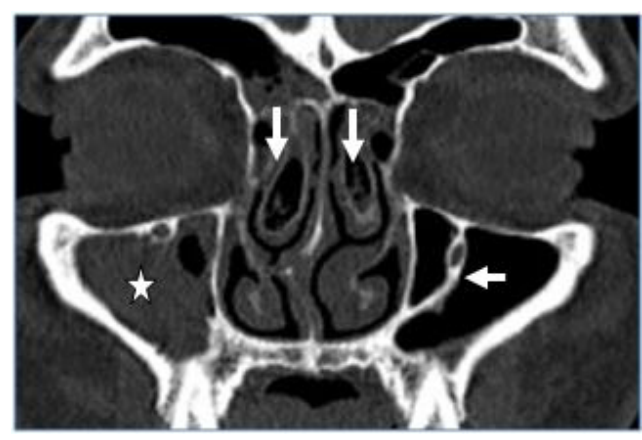

Table 4. Reported Age Groups / Mean Age For Presentation Of CRS By Various Authors.

\begin{tabular}{|c|c|c|}
\hline Name of authors & Year of study & Most common age group/mean age \\
\hline Bolger WE et al., [5] & 1991 & 37.1 years \\
\hline Basic N et al., [6] & 1999 & 42 years \\
\hline Joe JK et al., [7] & 2000 & 37 years \\
\hline Talaiepour AR et al., [8] & 2005 & 35.2 years \\
\hline Baradaranfar MH et al., [9] & 2007 & 34.46 years \\
\hline Saha et al., [10] & 2008 & $21-40$ years \\
\hline Sheetal D et al., [11] & 2011 & $20-40$ years \\
\hline In present study & $2015-2016$ & $21-30$ years \\
\hline
\end{tabular}

Table 5. Authors Reporting Female Preponderance In Their Studies.

\begin{tabular}{|c|c|c|}
\hline Name of author & Year of study & Percentage of females \\
\hline Basic N et al., [6] & 1999 & $63.20 \%$ \\
\hline Mahajan et al., [12] & 2003 & $56.45 \%$ \\
\hline Talaiepour AR et al., [8] & 2005 & $51.70 \%$ \\
\hline In present study & $2015-2016$ & $60.37 \%$ \\
\hline
\end{tabular}


et al., (1999) [17] 72.33\% cases and Talaiepour AR et al., (2005) [8] $63 \%$ cases. Our results of septal deviation are comparable to higher range reported.

In present study we have classified septal deviation depending upon the severity of deviation as mild, moderate and severe [18]. We found severe type of septal deviation as most common in $46(43.3 \%)$ cases, moderate in $30(28.3 \%)$ cases and mild in 12 $(11.3 \%)$ cases. Septal deviation with spur is seen in 40 cases of which 24 were on left side and 16 on right side. The prevalence of septal spur in our study was $37.73 \%$ and as reported by Danese et al., [19] is 33\% and by Jareoncharsri et al., [17] is $25.3 \%$. In present study septal pneumatization is seen in $50(47.1 \%)$ cases which are higher than those reported by Wang RG et al., (2003) in 18\% cases [20] and Chao TK (2005) in 2\% cases [21].

Aggernasi cells were seen in total $58(54.7 \%)$ cases of which 20 $(18.8 \%)$ had prominent aggernasi on right side \& $38(35.8 \%)$ had bilateral aggernasi. These findings correlates with studies of Talaiepour AR et al., (2005) [8] and Baradaranfar MH et al., (2006) [9] which reported the prevalence as $56 \%$ and $36 \%$ respectively.

In present study, concha bullosa was seen in $64(60.37 \%)$ cases that was bilateral in 30 (28.3), only right side in $22(20.75 \%)$ and only left side in $12(11.3 \%)$. The prevalence in our study correlates well with those reported by Bolger WE et al., [5] (1991) as 53\%, John Earwaker (1993) [22] as 55\% and Perez P et al., (2000) 73\% [23].

Paradoxically curved middle turbinate was reported in 28 (26.41\%) cases which included $20(18.8 \%)$ cases on left side and $4(3.7 \%)$ cases each on right side and bilaterally. These correlated well with study conducted by Bolger WE et al., (1991) who reported PMT in 26.1\% cases 5; Hosemann WG et al., (2000) [24] in 24\% and Rohit Saxena et al (2010) 14 in 32\%.

In our study, uncinate pneumatization was seen in $12(11.3 \%)$ cases of which $10(9.43 \%)$ were bilateral and only $02(1.89 \%)$ were on the right side. These findings correlated to Lloyd GAS et al., (1991) who reported $16 \%$ cases of uncinate pnuematization [25].
Ethmoid bulla was seen to be enlarged in $18(16.98 \%)$ cases where it was bilateral in $10(9.4 \%)$, only left side in $6(5.6 \%)$ and only right side in $2(1.89 \%)$. Incidence in present study correlated with the study of Lloyd GAS et al., [25] (1991) who reported enlarged ethmoid bulla in 18\% and Rohit Saxena et al., [14] (2009) in 16\%. (Table 6)

Haller cells were found in $18(16.98 \%)$ cases. These findings correlated with other studies such as $10 \%$ in Zinreich SJ et al., (1988) [16], 8\% in Pinas P et al., (2000) [23], 7\% in Hosemann WG et al (2000)24 and 9\% in Jones NS et al., (2002) [28].

Onodi cells were seen in $12(11.35 \%)$ cases which correlated well with other studies. Pinas P et al., in 2000 studied CT of 110 patients suspected of inflammatory disease and reported onodi cells in $11 \%$ cases [23].

In present study, superior attachment of UP found mainly to lamina papyracea in $70(66 \%)$ cases on left side and $48(45.2 \%)$ on right side. This was followed by attachment to middle turbinate seen in $40(37.2 \%)$ cases on right and 28 (26.4\%) on left. Attachment to skull base was seen in $18(16.9 \%)$ cases on right and $08(7.54 \%)$ on left.

Sheetal D et al., (2011) also reported superior attachment of UP most commonly to lamina papyracea $(70 \%$ on right side and $66 \%$ on left side) followed by the middle turbinate $(24 \%$ on right and $31 \%$ on left side) [11].

In present study we have found the most common appearance of frontal cell type I seen in $16(15.9 \%)$ cases followed by type II in $8(7.5 \%)$ cases, type III in $4(3.7 \%)$ and type IV in only $2(1.8 \%)$ cases.

Meyer TK et al., studied 768 scans and found type I frontal cells in $14.9 \%$ cases, type II in $1.3 \%$, type III in $1.7 \%$ and type IV in $2.1 \%$ [30]. Del Gaudio JM et al., (2005) studied 106 CT PNS and found type I frontal cells most common in $18.1 \%$ followed by type III in $6.1 \%$, type IV in $2.4 \%$ and type II in $1.4 \%$ cases [31]. Finding of

Table 6. Incidence Of Anatomical Variations On CT Scan In Patients Of CRS By Various Authors And Its Correlation With Present Study.

\begin{tabular}{|c|c|c|c|c|c|c|c|}
\hline Name of Author & AN & CB & PMT & PUP & EEB & Haller & Onodi \\
\hline Zinreich SJ et al., [16] in 1988 & Nearly all & $36 \%$ & $15 \%$ & $0.4 \%$ & $8 \%$ & $10 \%$ & - \\
\hline Lloyd GA et al., [26] in 1990 & $3 \%$ & $14 \%$ & $17 \%$ & $16 \%$ & $18 \%$ & $2 \%$ & - \\
\hline Bolger WE et al., [5] in 1991 & $98.50 \%$ & $53 \%$ & $26.10 \%$ & $2.50 \%$ & - & $45.10 \%$ & - \\
\hline Loyd GAS \& Lund VJ [25] in 1991 & $14 \%$ & $24 \%$ & $15 \%$ & - & - & $15 \%$ & - \\
\hline Milczuk HA et al., [27] in 1993 & - & $9.60 \%$ & $4.40 \%$ & - & - & $5.30 \%$ & - \\
\hline John Earwaker [22] in 1993 & $96 \%$ & $55 \%$ & $16.80 \%$ & - & - & $20 \%$ & - \\
\hline Pinas P et al., [23] in 2000 & Nearly all & $73 \%$ & $10 \%$ & $4.5 \%$ & - & $8 \%$ & $11 \%$ \\
\hline Hosemann WG et al., [25] in 2000 & $15 \%$ & $30 \%$ & $24 \%$ & - & - & $7 \%$ & - \\
\hline Jones NS et al., [28] in 2002 & $96.50 \%$ & $20 \%$ & $11.50 \%$ & $1.5 \%$ & $8.50 \%$ & $9 \%$ & $8 \%$ \\
\hline Talaiepour AR. et al., [8] in 2005 & $56 \%$ & $35 \%$ & - & - & - & $3.50 \%$ & - \\
\hline Baradaranfar MH et al., [9] 2006 & $36 \%$ & $12.50 \%$ & $1.67 \%$ & - & - & $4.17 \%$ & - \\
\hline Rohit Saxena et al., [14] in 2010 & $7 \%$ & $21 \%$ & $32 \%$ & $33 \%$ & $16 \%$ & - & - \\
\hline Vijay Bajaj et al., [29] in 2015 & $72.50 \%$ & $30 \%$ & $8.75 \%$ & $2.5 \%$ & $21.25 \%$ & $3.75 \%$ & $22.50 \%$ \\
\hline Present study (2015-2016) & $54.70 \%$ & $60.30 \%$ & $26.40 \%$ & $11.3 \%$ & $16.90 \%$ & $16.90 \%$ & $11.30 \%$ \\
\hline
\end{tabular}


our study correlated well with those studies.

\section{Severity of Concha Bullosa on CT imaging}

In present study, we found 94 concha bullosa in $64(60.3 \%)$ cases. Lamellar concha was most commonly seen in 40 (37.73\%) cases, bulbous and extensive concha bullosa seen in $12(11.32 \%)$ cases each. In 1991, Bolger WE et al., studied 202 patients and found lamellar concha in $46.2 \%$ cases, bulbous concha in $31.2 \%$ cases and extensive i.e. true concha bullosa in $15.7 \%$ cases [5]. Uygur T et al., in 2003 studied 100 consecutive patients of chronic sinusitis and found lamellar concha $55.3 \%$, bulbous in $33.97 \%$ and extensive in $10.8 \%$ cases [32].

Keles et al., in 2010 studied 90 patients of concha bullosa and found lamellar concha in $14.3 \%$ cases, $30 \%$ cases of bulbous concha and $44.4 \%$ cases were extensive or true concha bullosa [33]. The incidence of appearance of lamellar concha in present study correlated with Bolger WE et al., (1991) and Uygur et al., (2003).

\section{Septal Deviation and its Relation to Concha Bullosa}

In present study we found septal deviation and concha bullosa related to each other in its appearance. Concha bullosa with septal deviation on opposite side was found in 21 cases and on same side was found in 9 cases. But there was no significant association between side of septal deviation and presence of concha bullosa on contralateral side $[\mathrm{P}=0.25$ which is not significant because $\mathrm{P}>0.05]$.

The study conducted by Stallman et al., (2002) found significant association between the septal deviation and concha bullosa. They found that in patients with left sided unilateral, concha $117(70 \%)$ cases had right sided nasal septal deviation, $11(7 \%)$ cases had left sided nasal septal deviation and $38(23 \%)$ cases had no septal deviation [34].

Keles et al., (2010) evaluated relationship between nasal septal deviation and concha bullosa and reported that concha occurs more frequently on the opposite side of septal deviation $(50 \%)$ than to the side of septal deviation $(17.8 \%)$ cases [33]. Thus our findings correlates well with finding reported by Stallman et al. and Keles et al.,

\section{Involvement of Sinus on CT Imaging}

In present study we found most common sinus involved was maxillary, seen in $90(84.9 \%)$ cases followed by anterior ethmoids in $54(50.94 \%)$, frontal in $20(18.9 \%)$ and posterior ethmoids in $16(15.09 \%)$. Least common involved sinus was sphenoid in 14 $(13.2 \%)$ cases.

Calhoun et al., (1991) studied coronal CT sinus of 82 patients and found maxillary to be most commonly involved in $43 \%$ cases followed by anterior ethmoids in $34 \%$ and frontal sinus least [35].

Rohit Saxena et al., (2010) in his study of 60 cases found anterior ethmoids most commonly involved in 31 (51.7\%) followed by maxillary in $29(48.3 \%)$ cases [14]. Our findings correlated with Calhoun et al and Rohit Saxena et al in involvement of sinuses.

\section{Pattern of disease on CT Imaging}

In present study, OMC pattern was most commonly noted in 32 $(30.18 \%)$ cases followed by infundibular pattern in 31 (29.24\%), sporadic or unclassified unit pattern in $25(23.58 \%)$, sinonasal polyposis in $10(9.43 \%)$ and SER pattern in $8(7.54 \%)$ cases.

Sonkens et al., (1991) in 500 patients reported $26 \%$ infundibular pattern, 25\% OMC pattern, 6\% SER pattern, 10\% sinonasal polyposis and in $24 \%$ cases, sporadic pattern [36].

Lerdlum S et al., in 2005 evaluated screening sinus CT of 133 patients with inflammatory sinus disease and found that pattern I to be most common pattern of inflammatory disease $(33.1 \%)$ followed by pattern II in $25.6 \%$, pattern III in $24.4 \%$, pattern IV in $10.5 \%$ and pattern $\mathrm{V}$ in $19.9 \%$ [37].

Naimi M et al., in 2006 studied 200 coronal CT scans and reported OMC pattern as most common in $34 \%$ cases followed by sporadic pattern in $32 \%$, SER pattern in $24 \%$, sinonasal polyposis pattern $16 \%$ and least common infundibular pattern in $6 \%$ [38].

Eggesbo in 2006 studied patients undergoing sinonasal CT for suspected inflammatory sinonasal disease and reported infundibular and OMC patterns as most common (25\% each). The SER and sinonasal polyposis patterns are less common, and each is found in less than $10 \%$. The sporadic pattern is reported in $24 \%$ [39]. Our findings correlates well with these studies.

\section{Radiological Pattern of Disease and its Association with Anatomical Variation}

In the present study in bilateral cases of sinusitis presence of anatomical variation on each side was considered separately. OMC pattern was seen in $32(30.18 \%)$ cases which was associated with nasal septal deviation seen in 12, concha bullosa in 21 and PMT in 6 cases on same side of disease.

Infundibular pattern was seen in 31 (29.24\%) cases which were associated with deviated nasal septum in 21, concha bullosa in 18 and PMT in 14 cases on same side of disease. Out of $25(23.58 \%)$ cases of sporadic pattern, 14 cases were associated with nasal septal deviation, 6 cases with concha bullosa and 4 cases with PMT on same side of disease.

In $10(9.43 \%)$ cases of sinonasal polyposis pattern, we found septal deviation in 4 cases and concha bullosa in 6 cases, on same side of disease. In least common sphenoethmoidal recess pattern, we found 2 cases of septal deviation and 5 cases of PMT on same side of disease. OMC, infundibular and sporadic pattern were frequently associated with anatomical variation on same side.

Lerdlum S et al., (2005) studied 133 patients with inflammatory sinus disease and found that OMC pattern was associated with concha bullosa in 10 cases, infundibular pattern was associated with haller cells while aggernasi cells was associated with nasofrontal duct pattern [37].

\section{Types of Septal Deviation and its Relation with Sinusitis}

Out of 12 cases of mild septal deviation, $6(50 \%)$ cases were associated with sinusitis on same side. Out of 30 cases of 
moderate septal deviation, $21(70 \%)$ cases were associated with sinusitis on same side. Severe septal deviation was seen in 46 cases and in $26(56.52 \%)$ cases, it was associated with sinusitis on same side. The finding in this study shows strong association between moderate septal deviation and sinusitis on same side which was statistically significant [Chi-square test $\mathrm{x}^{2}=4.8, \mathrm{DF}=1, \mathrm{P}<0.02$ ].

\section{Type of Concha Bullosa and its Relation with Sinusitis}

In present study we found lamellar concha bullosa in $40(37.73 \%)$ cases, bulbous concha bullosa in $12(11.32 \%)$ cases and extensive concha bullosa in $12(11.32 \%$ ) cases. $62.5 \%$ (25 out of 40 ) cases of lamellar concha, $41 \%$ ( 5 out of 12 ) cases of bulbous concha and $66.66 \%$ (8 out of 12 ) cases of extensive concha were associated with disease on the side of concha. There was no significant association between the type of concha bullosa and sinusitis on same side of disease [P>0.05].

In 2005, Hatipoglu et al., found no significant difference between the type of concha and association of sinusitis on same side. They found sinusitis on same side in 58.34\% lamellar concha, 81\% extensive concha and $37 \%$ bulbous concha [40].

\section{Conclusion}

Rhinosinusitis commonly affects the working population with female preponderance. Anatomical variation is observed to be one of the predominant etiologies for osteomeatal complex block as well as sinusitis. Computed tomography is the paramount modality to study and analyze these anatomical variations.

There is a significant association of moderate septal deviation with sinusitis and no association of any single type of concha with sinusitis. Though anatomical variations are important in pathogenesis of sinusitis, their association could not be statistically proven.

\section{Acknowledgement And Declarations}

We would like to thank Dr. N.N. Dutta, CMD of downtown hospital for supporting us. We would also like to confirm that there are no conflicts of interest.

\section{References}

[1]. Stammberger H. Functional Endoscopic Sinus Surgery: The Messerklinger Technique. 1988;134(3)-23.

[2]. Stammberger H, Wolf G. Headaches and sinus diseases: The endoscopic approach. Ann OtolRhinolLaryngol Suppl. 1997;134:3-23.PubMed PMID:3140703

[3]. Komisar A. Nasal obstruction due to benign and malignant neoplasm. OtolaryngolClin North Am. 1989;22(2):351-65.PubMed PMID: 2664656.

[4]. Tondon PL, Gulati J, Mehta N. Histological study of polypoidal lesions in nasal cavity. N. Ind. J. Otol. 1971September;23(1):3-11.

[5]. Bolger WE, Butzin CA, Parsons DS. Paranasal sinus bony an anatomic variation and mucosal abnormalities: CT analysis of endoscopic sinus surgery. Laryngoscope 1991;101(1 Pt 1):56-64.PubMed PMID:1984551.

[6]. Basic N, Basic V, Jukic T, Basic M, Jelic M, Hat J. Computed et al. Computed tomographic imaging to determine the frequency of anatomical variations in pneumatization of the ethmoid bone. Eur Arch Otorhinolaryngol.. 1999;256(2):69-71. PubMed PMID: 10068893.

[7]. Joe JK, Ho SY, Yanagisawa E. Documentation of variations in sinonasal anatomy by intra-operative nasal endoscopy.Laryngoscope.2000Feb;110(2 Pt1):229-35. PubMed PMID: 10680921

[8]. Talaiepour AR, Sazgar AA, Baghe A. Anatomic Variations of the Paranasal
Sinuses on CT scan Images. Journal of Dentistry, Tehran University of Medical Sciences. 2005;2(4):142-146.

[9]. Baradaranfar MH, Labibi M. Anatomic variations of paranasal sinuses in patients with chronic sinusitis and their correlation with CT scan staging. ActaMedicaIranica 2007;45(6):77-480.

[10]. Saha KL, Taous A, MdRahman Z. Functional endoscopic sinus surgery for the management of sinonasal diseases. Bangladesh Journal of Otorhinolaryngology 2008;14(2):46-50.

[11]. Sheetal D, Devan P P, Manjunath P, Martin P, Satish Kumar K, Sreekantha, et al.- Do We Really Require Before Fess? Journal of Clinical and Diagnostic Research. 2011 Apr5(2):179-181.

[12]. Mahajan SB, Kochhar LK, Gupta AK. Sinugenic Headache and Nasal Endoscopy. Med J Armed Forces India2003 April59(2):121-124.PubMed PMID: 27407484.

[13]. Rowe-Jones JM, Shembekar M, Trendell-Smith N, Mackay IS. Polypoidal rhinosinusitis in cystic fibrosis: A clinical and histopathological study. ClinOtolaryngol Allied Sci. 1997;22(2):167-171.PubMed PMID: 9160933.

[14]. Saxena R, Vivek K, Mohit S. Role of CT paranasal sinuses and diagnostic nasal endoscopy inthe treatment modification of chronic rhinosinusitis. Gujarat Journal of Otorhinolaryngology and Head\& Neck Surgery 2010 June-July7(1):7.

[15]. Mamatha H, Shamasundar NM, Bharathi MB, Prasanna LC. Variations of osteomeatal complex and its applied anatomy: A CT scan study. Indian Journal of Science and Technology 2010 Aug3(8):904-907.

[16]. Zinreich SJ, Kennedy DW, Rosenbaum AE, Gayler BW, Kumar AJ, Stammberger HParanasal sinuses: CT imaging requirements for endoscopic surgery. Radiology 1987;163(3):769-75. PubMed PMID:3575731

[17]. Jareoncharsri P, Thitadilok V, Bunnag C, UngkanontK, Voraprayoon S, Tansuriyawong $\mathrm{P}$ Nasal endoscopic findings in patients with perennial allergic rhinitis. Asian Pac J Allergy Immunology. 1999 December 17(4): 261-7.

[18]. Janardhan Rao J, Vinay Kumar E. C, Ram Babu K, SathavahanaChowdary V, Jaswinder Singh, VineetaRangamani S.Classification of nasal septal deviation- relations to sinonasal pathology. Indian Journal of Otolaryngology and Head Neck Surgery 2005 July-September 57(3): 199-201.

[19]. Danese M, Duvoisin B, Agrifoglio A, Cherpillod J, Krayenbuhl M. Influence of naso-sinusal anatomic variants on recurrent, persistent or chronic sinusitis. X-ray computed tomographic evaluation in 112 patients. J Radiology. 1997 September78(9):651-7. PubMed PMID: 9537184

[20]. Wang RG, Zou YH, Han DY, Zhang W. Pneumatization of perpendicular plate of the ethmoid bone and mucocele. ZhonghuaEr Bi Yan HouKeZaZhi2003August38(4):279-81. PubMed PMID: 14743638.

[21]. Chao TK. Uncommon anatomic variations in patients with chronic paranasal sinusitis. Otolaryngol Head Neck Surg2005 February 132(2):221-5. PubMed PMID: 15692530.

[22]. Earwaker J. Anatomic variants in sinonasal CT. Radiographics 1993;13(1):381-415.PubMed PMID: 8460226.

[23]. Pinas P, Sabate J, Carmona A, Catalina C J, Jimenez J. Anatomical variations in the human paranasal sinus region studied by CT. J Anat2000;197:221227.PubMed PMID: 11005714.

[24]. Hosemann WG, Weber RK, Keerl RE, Lund VJ. Minimally Invasive Endonasal Sinus Surgery, Thieme, Stuttgart, New York. 2000; 3.

[25]. Lloyd GAS, Lund VJ, Scadding GK. CT of the paranasal sinuses and functional endoscopic surgery: a critical analysis of 100 symptomatic patients. J LaryngolOtol1991;105 (3):181-185. PubMed PMID: 2019802

[26]. Lloyd GA. CT of the paranasal sinuses: study of a control series in relation to endoscopic sinus surgery. J LaryngolOtol1990;104 (6):477-481.PubMed PMID: 2376707.

[27]. Milczuk HA, Dalley RW, Wessbacher FW, Richardson MA. Nasal and paranasal sinus anomalies in children with chronic sinusitis. Laryngoscope 1993Mar103(3):247-52.PubMed PMID: 8441311.

[28]. Jones NS. CT of the paranasal sinuses: A review of the correlation with clinical, surgical and histopathological findings. ClinOtolaryngol Allied Sci. 2002Feb27(1):11-7.PubMed PMID:11903365.

[29]. Vijay B, Bhoopendra S, Purohit JP. Prevelance of anatomical variations of lateral wall of nose in chronic sinusitis patients. Journal of Evolution of Medicine and Dental Sciences2015April32(4):5492-5505.

[30]. Meyer TK, Kocak M, Smith MM, Smith TL. Coronal computed tomography analysis of frontal cells. American Journal of Rhinology and allergy 2003May-June17(3)163-8.

[31]. Del Gaudio JM, Hudgins PA, Venkatraman G, Beningfield A. Multiplanar computed tomographic analysis of frontal recess cells: effect on frontal isthmus size and frontal sinusitis. Arch Otolaryngol Head Neck Surg. 2005Mar131(3):230-5.PubMed PMID: 15781763.

[32]. Uygur K, Tüz M, Doğru H. The correlation between septal deviation and concha bullosa. Otolaryngol Head Neck Surg2003;129(1):33-36.PubMed PMID: 12869913

[33]. BaharKeleş, KayhanÖztürk, DenizÜnaldı, HamdiArbağ, BedriÖzer. Is 
There any Relationship Between Nasal Septal Deviation and Concha Bullosa? European Journal of General Medicine 2010;7(4):359-364.

[34]. Jamie S Stallman, Joao N Lobo, Peter M Som. The Incidence of Concha Bullosa and Its Relationship to Nasal Septal Deviation and Paranasal Sinus Disease. American Journal of Neuroradiology October2004;25:1613-1618.

[35]. Calhoun KH, Waggenspack GA, Simpson CB, Hokanson JA, Bailey BJ. $\mathrm{CT}$ evaluation of the paranasal sinuses in symptomatic and asymptomatic populations. Otolaryngol Head Neck Surg1991 April104(4):480-3.PubMed PMID:1903859

[36]. Sonkens JW, Harnsberger HR, Blanch GM, Babbel RW, Hunt S. The impact of screening sinus $\mathrm{CT}$ on the planning of functional endoscopic sinus surgery. Otolaryngology Head Neck Surgery 1991December 105(6):802-13.
[37]. Lerdlum S, Vachiranubhap B. Prevalence of Anatomic Variations Demonstrated on Screening Sinus Computed Tomography and Clinical Correlation. J Med Assoc Thai 2005; 88(4):110-5. PubMed PMID:16623013

[38]. Naimi M, Bakhshaei M. The major obstructive inflammatory patterns of the sinonasal diseases in 200 candidates of functional endoscopic sinus surgery. The Iranian Journal of Otorhinolaryngology winter -2006;17(42):9-14

[39]. Eggesbø HB. Radiological imaging of inflammatory lesions in the nasal cavity and paranasal sinuses. European Radiology 2006April16(4):872-88.

[40]. HaticeGülHatipoğlu, Mehmet Ali Çetin, EnisYükse. Concha bullosa types: their relationship with sinusitis, osteomeatal and frontal recess disease. Diagnostic and Intervention Radiology 2005;11(3):145-149. 